\title{
Intercropping bean cultivars with plantain ${ }^{1,2}$
}

\author{
L. C. Liu', J. A. Rodriguez and Juan Ortiz \\ J. Agric. Univ. P.R. 81(3-4):151-158 (1997) \\ ABSTRACT
}

\begin{abstract}
Two bean (Phaseollus vulgaris L.) cultivars, Arroyo Loro and DOR 364, and four lines, 9443-1, 9443-8, 9443-33, 9226-17, were intercropped once or twice with one cycle of plantain cultivar Maricongo at the AES-UPR Corozal substation during 1994-1995. The first cycle of beans intercropped at the time of plantain planting produced a high yield. The second cycle of beans intercropped two months before the termination of plantain harvest yielded poorly. The height of intercropped plantain plants was less than that of nonintercropped plantain plants $(P<0.05)$ at six months after planting. However, at 12 months, there was no height difference between them. There was no significant difference in diameter of pseudostem, nor in number of leaves, between the intercropped and the non-intercropped plantain plants. Plantain yields, in terms of number of fruits and bunch weight, were not significantly affected by the intercropping $(P<0.05)$. The highest net income of the intercropping treatment was derived from the first cycle of the bean line 9443-1 ( $\$ 7,646 / \mathrm{ha})$. This net income represents an additional income of $\$ 4,894 /$ ha beyond that of plantain monoculture.
\end{abstract}

Key words: intercropping, bean, plantain

\section{RESUMEN}

Intercalando habichuelas con platano

Durante el año 1994-1995, dos cultivares de habichuelas, Arroyo Loro y DOR 364 , y cuatro líneas $9443-1,9443-8,9443-33$ y 9226-17, se intercalaron una o dos veces dentro de un ciclo de siembra de plátanos en la subestación de Corozal, EEA-UPR. La primera siembra de habichuela intercalada se estableció al momento de la siembra de los plátanos, obteniéndose una buena producción. La segunda siembra de habichuela intercalada se estableció dos meses antes de terminar la cosecha de plátanos, obteniéndose un rendimiento menor que en la primera siembra. A los seis meses después de la siembra, las plantas de plátanos no intercalados eran significativamente más altas que las plantas de los plátanos intercalados. Sin embargo, 12 meses después de la siembra no había diferencia significativa. Además, no hubo diferencias entre los plátanos intercalados y no intercalados en el diámetro del pseudotallo ni en el número de hojas de plátanos. El rendi-

'Manuscript submitted to Editorial Boaxd 20 August 1996.

${ }^{2}$ We are grateful to Dr. James Beaver; Plant Breeder, Agronomy Department of Agronomy and Soils, College of Agricultural Sciences, Univ. P.R. for supplying seed of the bean lines used in this study. We appreciate the financial support of the Science and Technology Board, Economic Development Administration, Government of Puerto Rico.

Plant Physiologist, Agricultural Experiment Station, P.O. Box 21360, Río Piedras, P.R. 00928

'Agronomist, Agronomy and Soils Department.

"Agricultural Economist, Agricultural Economics and Rural Sociology Dept. 
miento del plátano no se afectó por el intercalado. El mayor ingreso neto $(\$ 7,646 /$ ha) se obtuvo en el primer ciclo de la habichuela linea 9443-1 intercalada una vez con plátano. Este ingreso neto representa una ganancia adicional de $\$ 4,894 / \mathrm{ha}$ sobre el ingreso neto del platano en monocultivo.

\section{INTRODUCTION}

Intercropping is a widespread agronomic practice on subsistence farms in developing countries of the tropics (Francis et al., 1976). In southeastern Nigeria, plantain (Musa acuminata $\times M$. balbisiana, $\mathrm{AAB}$ ) is frequently intercropped with cocoyam (Devo et al., 1978) and cassava (Uzozie, 1971). In the Andean region of South America, plantain has been intercropped with coffee, cocoa, maize, cassava and bean (Stover and Simmonds, 1987). In Colombia, Valencia et al. (1995) conducted an intercropping experiment where plantain was intercropped with maize, cassava and bean. They reported that plantain yield was not affected by intercropping with any of the three above mentioned crops. Banana and plantain are frequently a permanent intercrop with coffee at populations of 400 to 1,000 plants per hectare in Columbia (Stover, 1983). The intercropping of cowpeas, maize and sweet potatoes with banana was studied in the West Indies by Rao and Edmund (1984). They did not find any significant reductions of banana bunch weight by the intercropping of the above mentioned crops. In Puerto Rico, Rodríguez et al. (1981) intercropped plantain with tanier at Corozal and reported that yield of tanier was reduced by $40 \%$. However, they did not mention whether or not the plantain yield was reduced. In Puerto Rico, beans are already intercropped with plantains by a small number of farmers but there is no data concerning the economics of this practice. Neither is there any information available with regard to the field performance of the six bean cultivars under our specific intercropping conditions.

Since bean is a short term crop with some degree of shade tolerance, it may be suitable for intercropping with a long-term plantain crop. By the time the leaf canopy of plantain completely closes in, the bean crop will already have been harvested. More importantly, the long-term growing plantain requires 14 to 18 months to harvest a plant crop. This growth period represents a long wait for plantain farmers to recover their investment. Any additional income that can be earned from the same field during the wait for harvest would be financially attractive.

With this economic benefit in mind, we have conducted this field experiment at the AES Corozal Experiment Station to determine 1) the effect of intercropping on growth parameters and yield of plantain; 2) the economic benefit that can be derived from different bean cultivars and lines intercropped with plantain. 


\section{MATERIALS AND METHODS}

A field experiment on bean-plantain intercropping was established on a Corozal clay (Clayey, mixed, isohyperthermic Aquic Haplohumults) 25 April 1994 at the AES, Corozal. The Corozal station is located in the north central part of the island. The Corozal clay soil has a $\mathrm{pH}$ of 5.0 , and N, P, K, Ca, Mg content of $0.19 \%, 6 \mathrm{mg} / \mathrm{kg}, 1.35 \mathrm{cmol} / \mathrm{kg}, 3.95 \mathrm{cmol} /$ $\mathrm{kg}, 0.70 \mathrm{cmol} / \mathrm{kg}$, respectively. Two bean cultivars, Arroyo Loro and DOR 364, and four bean lines, 9443-1, 9443-8, 9443-33, 9226-17, were selected for the experiment. Treatments consisted of one bean-plantain intercropping (at the time of plantain planting), and two bean-plantain intercroppings (at the plantain planting and two months before the end of plantain harvest). The plantain cultivar used was Maricongo. A plantain monoculture treatment was also included. All treatments were arranged in a randomized complete block design with four replications. Each plot contained six plantain plants with a planting distance of 1.8 $\times 2.7 \mathrm{~m}$ instead of the recommended distance of $1.8 \times 1.8 \mathrm{~m}$. This planting distance provides more space for the intercropping of beans. Eight 1.8-m-long rows of beans with row spacing of $51 \mathrm{~cm}$ were intercropped with two rows of plantain in each plot. The planting distance between the bean plants was $8 \mathrm{~cm}$. The slope of the land used for this experiment was 15 to $20 \%$. Both plantain and bean were planted perpendicularly to the down slope direction of the experiment. Fertilizer (10-05-20 with Sulpomag) was applied in $232,309,347$ and $270 \mathrm{~g} / \mathrm{plant} /$ application at $2,5,8$, and 11 months after planting, respectively. The bean plants received one application of $\mathrm{N}, \mathrm{P}, \mathrm{K}$ fertilizer at a rate equivalent to 22,11 and $22 \mathrm{~kg} / \mathrm{ha}$, respectively, two weeks after planting. All other agronomic and pest managements were in accordance with the recommended practices for growing plantains and beans (Irizarry and Montalvo, 1995; Beaver et al., 1992). A sprinkler irrigation system was used to supplement the natural rainfall. Growth parameters such as plant height, diameter of pseudostem and number of leaves per plant of the plantain plants, were recorded at the appropriate times. Bean plants were harvested nine weeks after planting. Plantain fruits were harvested at the mature-green stage during a time period of 12 to 18 months after planting. Yield data of both crops were subjected to anal$y$ sis of variance and Duncan's Multiple Range Test $(\mathrm{P}<0.05)$.

\section{RESULTS AND DISCUSSION}

Growth parameters

There was an initial height reduction of plantain plants at six months after planting in all intercropped treatments as compared to 
the plantain monoculture (Table 1). However, this height reduction was no longer evident by the end of 12 months. There were no significant differences in diameter of pseudostem nor in number of leaves between the intercropped plantain plants and plantain monoculture.

Bean yield

The highest whole pod and green-shell bean yields were obtained with the 9443-33 and the 9443-1 bean lines during the first cycle of intercropping (Table 2). However, not all yield differences among treatments were significant. The same results were obtained for the total bean yield (Table 2). In general, bean yield of all lines and cultivars was considered good. Lower yields were obtained from all lines and cultivars of bean during the second cycle of intercropping (Table 2). The low bean yields obtained from the second cycle of bean contributed very little to the total yield. Apparently, the shading effect of plantain canopy and the falling of the harvested plantain pseudostems over the second cycle of intercropped bean plants, coupled with high rainfall that prevailed during the germinating period of beans, caused these low yields. Therefore, we do not recommend a second cycle of bean in-

TABLE 1.-Effect of bean intercropping on growth parameters and yield of plantain. cullivar Maricongo during 1994-1995.

\begin{tabular}{|c|c|c|c|c|c|c|}
\hline Treatment & Plant h & $12 \mathrm{mo}$ & $\begin{array}{l}\text { Diameter of } \\
\text { psuedostem }\end{array}$ & $\begin{array}{c}\text { Number } \\
\text { of } \\
\text { leaves }\end{array}$ & $\begin{array}{c}\text { Number } \\
\text { of } \\
\text { fruits }\end{array}$ & $\begin{array}{l}\text { Fruit } \\
\text { bunch } \\
\text { weight }\end{array}$ \\
\hline & $\mathrm{m}$ & $\mathrm{m}$ & $\mathrm{cm}$ & No/plant & No/ha & $\mathrm{kg} / \mathrm{ha}$ \\
\hline $\begin{array}{l}\text { Arroyo Loro } \\
\text { (one intercropping) }\end{array}$ & $0.96 c^{\prime}$ & $3.93 \mathrm{a}$ & $18.3 a$ & $12 \mathrm{a}$ & $76,987 a$ & $24,144 \mathrm{a}$ \\
\hline 9443-1 (one) & $1.14 \mathrm{bc}$ & $3.96 \mathrm{a}$ & $18.7 \mathrm{a}$ & $13 a$ & $92,020 \mathrm{a}$ & $29,185 a$ \\
\hline $9443-8$ cone & $1.05 \mathrm{bc}$ & $3.90 \mathrm{a}$ & $18.5 \mathrm{a}$ & $13 a$ & $74,330 \mathrm{a}$ & $22,436 \mathrm{a}$ \\
\hline $9443-33$ (one) & $0.88 \mathrm{c}$ & $3.84 \mathrm{a}$ & $18.5 \mathrm{a}$ & $13 a$ & $78,650 \mathrm{a}$ & $24,660 \mathrm{a}$ \\
\hline 9226-17 (one) & $0.91 \mathrm{e}$ & $3.91 a$ & $18.8 \mathrm{a}$ & $13 a$ & $78,066 a$ & $23,079 a$ \\
\hline DOR 364 (one) & $0.97 \mathrm{c}$ & $3.91 a$ & $18.3 a$ & $12 a$ & $64,281 \mathrm{a}$ & $20,097 \mathrm{a}$ \\
\hline $\begin{array}{l}\text { Arroyo Loro } \\
\text { (two intercroppings) }\end{array}$ & $1.01 b c$ & $3.83 a$ & $18.9 \mathrm{a}$ & $12 \mathrm{a}$ & $73,500 \mathrm{a}$ & $22,835 \mathrm{a}$ \\
\hline $9443-1($ two $)$ & $1.09 b c$ & $3.83 \mathrm{a}$ & $18.4 \mathrm{a}$ & $12 a$ & $89,030 \mathrm{a}$ & $27,811 \mathrm{a}$ \\
\hline $9443-8\left(t w_{0}\right)$ & $1.08 \mathrm{bc}$ & $3.73 \mathrm{a}$ & $18.2 \mathrm{a}$ & $13 \mathrm{a}$ & $74,414 a$ & $21,682 a$ \\
\hline $9443-33$ (two) & $1.27 \mathrm{~b}$ & $3.93 a$ & $18.8 \mathrm{a}$ & $13 \mathrm{a}$ & $79,561 \mathrm{a}$ & $26,057 \mathrm{a}$ \\
\hline 9226-17 (two) & $0.97 \mathrm{c}$ & $3.89 a$ & $18.2 \mathrm{a}$ & $13 a$ & $75,909 a$ & $24,517 \mathrm{a}$ \\
\hline DOR 364 (two) & $1.05 \mathrm{bc}$ & $3.97 \mathrm{a}$ & $18.5 a$ & $13 a$ & $86,705 \mathrm{~d}$ & $26,583 a$ \\
\hline Plantain monoculture & $1.85 \mathrm{a}$ & $3.62 \mathrm{a}$ & $18.5 \mathrm{a}$ & $13 a$ & $73,831 a$ & $24,069 a$ \\
\hline
\end{tabular}

'Means followed by the same letter or letters do not differ significantly at. $P<0.05$. 
TABLE 2.-Total and partial yields of two bean cultivars and four lines under two frequencies of intercropping with plantain (Maricongo), at Corozal during 1994-1995.

\begin{tabular}{|c|c|c|c|c|c|c|}
\hline \multirow[b]{2}{*}{ Cultivars } & \multicolumn{3}{|c|}{ Whole pod yield } & \multicolumn{3}{|c|}{ Green-shell bean yield } \\
\hline & 1st cycle & 2nd cycle & Total & 1st cycle & and cycle & Total \\
\hline \multicolumn{7}{|c|}{ 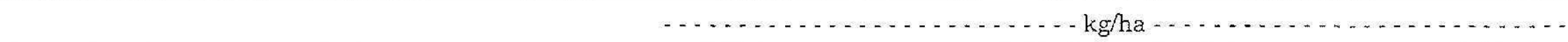 } \\
\hline Arroyo Loro (one intercropping) & $4,712 \mathrm{abc}$ & $\rightarrow$ & $4,712 \mathrm{bcd}:$ & $2,387 a b^{\prime}$ & - & $2,387 \mathrm{ab}$ \\
\hline $9443-1$ (one int.) & 5,470 ab & - & $5,470 \mathrm{ab}$ & $2,983 \mathrm{a}$ & - & $2,983 a$ \\
\hline $9443-8$ (one int.) & $2,668 \mathrm{de}$ & - & $2.668 \mathrm{e}$ & $1,451 \mathrm{~cd}$ & - & $1,451 \mathrm{bcd}$ \\
\hline $9443-33$ (one int.) & $3,619 \mathrm{cde}$ & - & $3,619 \mathrm{de}$ & $1,701 \mathrm{bcd}$ & - & 1,701 bcd \\
\hline 9226.17 (one int.) & $2,169 \mathrm{e}$ & - & $2,169 \mathrm{e}$ & $1.104 \mathrm{~d}$ & - & $1,104 \mathrm{~cd}$ \\
\hline DOR 364 (one int.) & $4,152 b c$ & - & $4,152 \mathrm{~cd}$ & $2,073 \mathrm{abcd}$ & - & $2,073 a b c$ \\
\hline Arroyo Loro (two intercroppings) & $3,691 \mathrm{bcd}$ & $191 a b$ & $3,882 \mathrm{~cd}$ & $1,796 \mathrm{abcd}$ & $98 a b$ & $1,894 \mathrm{abc}$ \\
\hline $9443-1$ (two int.) & $3,941 \mathrm{bc}$ & $164 \mathrm{abc}$ & $4,105 \mathrm{~cd}$ & $2,040 \mathrm{abcd}$ & $85 a b c$ & $2,125 \mathrm{ab}$ \\
\hline $9443-8$ (two int.) & $3,192 \mathrm{cde}$ & $118 \mathrm{bc}$ & $3,310 \mathrm{de}$ & $1,844 a b c d$ & $61 b c$ & $1,905 a b c$ \\
\hline $9443-33$ (two int.) & $6,121 \mathrm{a}$ & $85 \mathrm{c}$ & $6,206 a$ & $3,565 \mathrm{a}$ & $43 c$ & $3,608 \mathrm{a}$ \\
\hline $9226-17$ (two int.) & $1,683 e$ & $151 \mathrm{abc}$ & $1,834 \mathrm{e}$ & $907 d$ & $78 a b c$ & $985 \mathrm{~cd}$ \\
\hline DOR 364 (two int.) & $4,809 a b$ & $222 \mathrm{a}$ & $5,031 \mathrm{ab}$ & $2,042 \mathrm{abcd}$ & $118 \mathrm{a}$ & $2,156 \mathrm{ab}$ \\
\hline
\end{tabular}

Neans followed by the same letter or letters do not differ significantly at $\mathrm{P}<0.05$. 
tercropping toward the end of the plantain growing season. There was a minor infection of the angular leaf stain disease (Phaeoisariopsis griseola) among all lines and cultivars of bean tested. The 9443-33 line was noted for its high susceptibility to the golden mosaic virus in this experiment.

Plantain yield

No significant differences in number of fruits and bunch weight were found among the treatments (Table 1). Our finding that plantain yield was not affected significantly by intercropping is in agreement with the work reported by Valencia et al. (1995). Apparently, the initial height reduction in plantain plants observed at six months after planting was due to the competition for nutrients and water between plantain and bean plants. As soon as the bean plants were harvested, this competition no longer existed. Plantain plants were able to recover from this initial stress.

Economic feasibility

In this experiment, the highest net income $(\$ 7,646 / \mathrm{ha})$ was derived from one cycle of intercropping of bean line 9443-1 with plantain (Table $3)$. This net income represents an additional income of $\$ 4,894$ over that of plantain monoculture. It is important to note that not all bean cultivars produced higher net income than plantain monoculture. Therefore, the selection of high yielding bean cultivars for intercropping is of critical importance to profitability. In addition, farmers could receive reimbursement for supplementary wage payment of $\$ 2.12$ per hour from the Commonwealth Government of Puerto Rico.

For legal use under commercial intercropping conditions, a pesticide has to be registered for both plantain and bean crops. However, fenamiphos (Nemacur) is registered only for plantain, not for bean. Therefore, fenamiphos can not be used legally for the intercropped bean. Its use on plantain either will have to be delayed until after the harvest of bean or will have to wait until its registration for bean. The issue of pesticide usage for both intercropped crops is complex and will continue to be a problem for those farmers choosing to adopt this intercropping practice. 
TABLE 3.-Gross and net incomes derived from one and two intercroppings of bean with plantain and plantain monoculture in a field experinent at Corozal Station, AES-UPR during 1994-1995.

\begin{tabular}{|c|c|c|c|c|c|c|c|}
\hline \multirow[b]{2}{*}{ Truatment } & \multicolumn{3}{|c|}{ Gross income } & \multicolumn{3}{|c|}{ Variable costs } & \multirow{2}{*}{$\begin{array}{l}\text { Net } \\
\text { income }\end{array}$} \\
\hline & Bean & Plantain & Total & Bean & Pantain & Total & \\
\hline & & & & $\$ /$ ha - - - & $\ldots \ldots$ & $\cdots \ldots$ & ..... \\
\hline Amoyo Loro lone intercrop, & $8,4 \pi 4$ & 10,648 & 19,122 & 7,024 & $7,862:$ & 14,886 & 4,236 \\
\hline $94+3-1$ ione & 10,590 & 12,871 & 23,461 & 7,953 & 7,862 & $15,81.5$ & 7,646 \\
\hline $9443-8$ lone & 5,151 & 9,894 & 15,045 & 4,949 & 7,862 & 12,811 & 2,234 \\
\hline $9443-33$ (one) & 6,039 & 10,875 & 16,914 & 5,795 & 7,862 & 13,657 & 3,257 \\
\hline $9226-17$ (one) & 3,919 & 10,178 & 14,097 & 4,366 & 7,862 & 12,228 & 1,869 \\
\hline DOR 364 one & 7,359 & 8,863 & 16,222 & 6,419 & 7,862 & 14,281 & 1.941 \\
\hline Arroyo Loro itwo intercrops & 6,724 & 10,070 & 16,794 & 7,705 & 7.862 & 15,567 & 1,227 \\
\hline $9413-1$ (two $)$ & 7,544 & 12,265 & 19,809 & 7,591 & 7,862 & 15,453 & 4,356 \\
\hline $9443-8$ itwo) & 6,763 & 9,562 & 16,325 & 8,202 & 7,862 & 16,064 & 261 \\
\hline $9443-33$ (two) & 12,808 & 11,491 & 24,299 & 10,534 & 7,862 & 18,396 & 5,903 \\
\hline $9226-17$ (two) & 3,497 & 10,812 & 14,309 & 5,607 & 7.862 & 13.469 & 840 \\
\hline DOR 364 (two) & 7,654 & 11,723 & 19,377 & 8,636 & 7,862 & 16,498 & 2.879 \\
\hline PJantain monoculture & 0 & 10,614 & 10,614 & 0 & 7,862 & 7,862 & 2,752 \\
\hline
\end{tabular}

Bean price was estimated at $\$ 3.55 / \mathrm{kg}$ of green-shelled beans.

Tlantain price was estimated at $\$ 0.441 / \mathrm{kg}$ of fruit bunch weight.

Variable costs for beans were calculated on the basis of an estimated cost of $\$ 7,065 / \mathrm{ha}$.

Variable costs for plantain were taken from the "Conjunto Tecnológico para la producción de plátanos y guineos", Publicación 97.1995 (Edición Revisada), FFA, UPR. 


\section{LITERATURE CITED}

Beaver, J. S., R. Echavez-Badel, A. M. Armstrong and E. Schroeder, 1.992. Conjunto tecnológico para la producción de habichuelas. Estación Experimental Agricola, Colegio de Ciencias Agrícolas, Recinto Universitario de Mayagüez, Univ. de P.R.

Devo, P. and S. F. Wilson, 1978. Productivity and efficiency of plantain-cocoyam intercropping. Paradisaca No. 3(6-11) SSTA, lbadan, Nigeria.

Francis, C. A., C. A. Flor and S. R. Temple, 1976. Cultivars for intercropping in the tropics. In: Multiple cropping, edited by Agronomy Society of America, Special publication. p. 235-253.

Irizarry, H. and R. Montalvo-Zapata, 1995. Conjunto tecnologico para la producción de plátanos y guineos. Estación Experimental Agrícola, Recinto Universitario Mayagüez, Universidad de P.R. Publ. 97.

Rao, M. M. and J. E. Edmund, 1984. Intercropping of banana with food crops: Cowpeas, maize and sweet potatoes. Tropic Agric. 60:9-11.

Rodríguez, J. A., F. Abruña and N. Díaz, 1981. Effect on tanier yields of artificial shade level and of intercropping with plantains. J. Agric. Univ. P.R. 45:326-330.

Stover, R. H., 1983. Intensive production of horn type plantain (AAB) with eoffee in Columbia, Fruits 38:765-70.

Stover, R. H. and N. W. Simmonds, 1987. Bananas 3rd Ed.Longman Scientific \& Technical, John Wiley \& Son, New York.

Uzozie, 1.C., 1971, Pattern of crop combination in the three eastern states of Nigeria. $J$. of Tropic Georgr. 33:62-67.

Valencia, M. J. A., S. C. Belalcázar, M. I. Arcila, H. R. Garcia R. and A. González, 1995. Efecto del intercalamiento simultáneo de frijol, maíz y yuca sobre el crecimiento y la producción de plátano del clon Dominico Hartón, Musa AAB Simmonds. Nueva tecnologia para la producción de plátano 63-70. JCA-CORPOICA AA 1069, Armenia, Quindio. 